\title{
Preferred Entry Mode Choices and Transformation of Indonesian Contractors' Strategy in International Markets
}

\author{
"Wahyudi P Utama',2, Albert PC Chan², Hafiz Zahoor 3 , Ran Gao and \\ Zulherman'
}

Published online: 31 December 2019

To cite this article: Wahyudi P Utama, Albert PC Chan, Hafiz Zahoor, Ran Gao and Zulherman (2019). Preferred entry mode choices and transformation of Indonesian contractors' strategy in international markets. Journal of Construction in Developing Countries, 24(2): 173-188. https://doi.org/10.21315/jcdc2019.24.2.8.

To link to this article: https://doi.org/10.21315/jcdc2019.24.2.8

\begin{abstract}
The selection of an appropriate entry strategy is an essential stage to expand business to overseas markets. Few studies have been undertaken to investigate this issue in the context of construction industry from the developing economies. This study aims to empirically investigate the entry strategy adopted by Indonesian contractors and observe the transformation of strategy to enter overseas construction markets (OCMs). Combination quantitative and qualitative research approaches was adopted to achieve the objectives. Data were obtained from survey of 103 Indonesian large contractors from 317 samples. Descriptive statistic and relative importance index (RII) were employed to analyse the data in which the results were then triangulated with interview findings. The results indicated those joint venture projects (JVP), branch office (BO) and representative office (RO) are the preferred entry mode choice adopted by Indonesian contractors. Four types of entry strategy transformation were identified. Each types of transformation showed that JVP or sole venture project (SVP) is directly used to pursue projects while BO or RO is set after operating for several projects. This study may provide a profound insight based on developing industries' experiences. For future research direction, the selection of entry mode by investigating the considerations influencing entry mode choice is encouraged.
\end{abstract}

Keywords: International expansion, Construction project, Market entry strategy, Entry mode, Indonesian contractor

\section{INTRODUCTION}

In the history of the global development economics, the international construction has been thought of as a crucial component. It is a key instrument for triggering the increase in other economic sectors. One of the important current discussions in this context is the strategy to enter overseas markets from developing construction economies.

Entry mode is a form of system arrangement, a way of transferring product, technology, manpower, management experience and other resources into other countries (Li et al., 2013). Similarly, Chen and Messner (2011) defined this term as an institutional arrangement that makes possible entry of a company's products,

\footnotetext{
'Department of Quantity Surveying, Universitas Bung Hatta, INDONESIA

${ }^{2}$ Department of Building and Real Estate, The Hong Kong Polytechnic University, HONG KONG

${ }^{3}$ Department of Construction Engineering and Management, National University of Sciences and Technology, Risalpur Campus, PAKISTAN

${ }^{4}$ School of Management Science and Engineering, Central University of Finance and Economics, Beijing, CHINA

"Corresponding author: wahyudi@bunghatta.ac.id
} 
technology, human skills, management, or other resources into a foreign country. Shortly, entry mode is a predicate for describing company's action enabling company to penetrate foreign markets.

Study by Utama et al. (2016) witnesses that statistically, most of international construction research has been monopolised by developed construction industries, while research activities have overlooked the participation of developing economies. Fortunately, in the last decades, Malaysian researcher (i.e. AbdulAziz and Wong, 2010; Abdul-Aziz and Law, 2012; Preece et al., 2016) and Pakistani scholars (i.e. Maqsoom et al., 2014) have paid attention to this area, while China has substantially shown their researchers performance (i.e. Pheng and Hongbin, 2003; Chen and Orr, 2009) in advance. Of interest in the growth involvement of developing economies in this business is the strategy to enter foreign markets by Indonesian contractors.

In the absence of studies relating to this domain in the context of developing construction industries like Indonesian, a research conducted to narrow the gap is important and valuable. The objective of this study is, therefore, to empirically investigate the entry strategy adopted by Indonesian contractors and to observe the transformation of strategy to enter overseas construction markets (OCMs). Descriptive statistical analysis and relative importance index were use as primary tool to analyse data derived from questionnaire survey. Meanwhile, interview series were conducted to provide support and apprehend the issues. Findings of both sources were then triangulated to deduce the results.

\section{LITERATURE REVIEW}

The entry mode as indicated above, is an institutional arrangement to mobilise a company's products and assets such as expertise, technology, resources and management to set up business activities in foreign markets. In most literature about entry mode, strategic management and general international business are the leading body of knowledge (Chen and Messner, 2009; 2011). Therefore, the vast majority of theories related to entry strategy were adopted from the context of general international trading (Pan and Tse, 2000; Chen and Mujtaba, 2007). Entry mode, entry strategy and market entry are terms frequently used interchangeably.

In terms of general business strategy, experts have classified the institutional arrangements in a variety of classes. They are classified based on the institutional dimensions namely (1) cooperative or competitive, (2) hierarchical levels, (3) contractual or investment, (4) ownership, (5) supportive or main, (6) permanent or mobile and (7) hierarchy or market (Chen and Messner, 2011). In the context of construction business, Li et al. (2013) agree with Root (1994) who classifies entry modes into export, contractual and investment modes, but Ling, lbbs and Cuervo (2005) grouped them into four categories: wholly owned subsidiaries, equity joint venture, project joint venture and other alliances.

However, due to the character of the construction industry as a service business, which is project-based industries, not all entry modes are applicable in this sector (Chen and Messner, 2011). Chen (2008) further emphasised that construction industry needs to make adjustment on any concept of theories adopted from the manufacturing sector. Thus, this present study adopts 10 entry modes generally applied in the construction industry, which is comprehensively defined by Chen and Messner (2009) as presented in Table 1. 
Table 1. Types of Entry Mode

\begin{tabular}{|c|c|}
\hline Entry Mode & Definition \\
\hline Strategic alliance & $\begin{array}{l}\text { Create a mutual cooperation commitment in long } \\
\text { term with other parties (local or overseas) for sharing } \\
\text { resources, advantages and responsibilities. }\end{array}$ \\
\hline Local agent (LA) & $\begin{array}{l}\text { Appoint an agent in host country where the agents } \\
\text { provide some service such information about market } \\
\text { conditions, projects, contracts and other assistance. }\end{array}$ \\
\hline Licensing & $\begin{array}{l}\text { Use other party's licenses in host country where the } \\
\text { entrant has limited rights over the use of resources such } \\
\text { as patents, technology, and management expertise. }\end{array}$ \\
\hline Joint venture company (JVC) & $\begin{array}{l}\text { Establish new business entity permanently with foreign } \\
\text { or local partners. }\end{array}$ \\
\hline Sole venture company (SVC) & $\begin{array}{l}\text { Establish new company in overseas where the } \\
\text { company's advantages and responsibilities fully owned } \\
\text { by the founder. }\end{array}$ \\
\hline Branch office $(\mathrm{BO})$ & $\begin{array}{l}\text { Open overseas branch which can carry out business } \\
\text { activities either profit making or non-profit making. }\end{array}$ \\
\hline Representative office (RO) & $\begin{array}{l}\text { Open overseas RO to carry out non-commercial } \\
\text { business activities such as communication, promotion } \\
\text { or market research on behalf of the parent company. }\end{array}$ \\
\hline Joint venture project (JVP) & $\begin{array}{l}\text { Cooperate with other companies to conduct a } \\
\text { particular project in which the advantages and } \\
\text { responsibilities are divided based on a contract. }\end{array}$ \\
\hline Sole venture project (SVP) & $\begin{array}{l}\text { Compete directly against a project in which the } \\
\text { advantages and responsibilities wholly owned } \\
\text { company. }\end{array}$ \\
\hline $\begin{array}{l}\text { Build-operate-transfer (BOT)/ } \\
\text { equity project }\end{array}$ & $\begin{array}{l}\text { Finance and construct an infrastructure project in host } \\
\text { country, operate it for a certain period and then hand } \\
\text { over the ownership of project to the host government } \\
\text { at the end of consensus. }\end{array}$ \\
\hline
\end{tabular}

\section{RESEARCH METHOD}

This study employed both quantitative and qualitative research approaches due to the lack of a sole technique to satisfactorily and comprehensively address a phenomenon like entry strategy in OCMs. The data was collected through questionnaire survey distributed to Indonesian large size contractors, qualified as Grade 6 and 7 or Class B1 and B2 in Jakarta. Using the Equation 1 (Czaja and Blair, 1996; Akadiri, 2011), the sample size of research was 317 respondents $(8.05 \%$ of the number of Indonesian large contractors). The large contractors were listed and obtained from Indonesian Contractors Association (Asosiasi Kontraktor Indonesia [AKI]) and Indonesian National Builders Association (Gabungan Pelaksana Konstruksi Nasional Indonesia [Gapensi]).

$$
s s=\frac{z^{2} \cdot p(1-p)}{c^{2}}
$$


Likert scale with seven-scale opinion was used since it is more reliable and valid than the shorter or longer scales (Tjandra, 2004). Scale 1 indicates "Not Important at All" and 7 represents "Extremely Important". The questionnaire principally consists of two sections. Section A comprises a list of questions about the respondents and participating firms' demography. Section B encloses the primary types of the entry modes, which are preferred to increase the likelihood of success in gaining and sustaining the OCPs. Based on experience of Willard (2012) in collecting data involving Indonesian informants, the distribution of questionnaires combined two ways, hand-delivery and postal service. Of 317 questionnaires dispatched to selected samples, 103 responses (32.50\%) were received after intensifying multiple efforts including repeated calls and emails and using internal links and colleague networking. Results of questionnaire analysis were then supported by the interviews.

Six practitioners, two academicians and one governmental officer were interviewed to explore the company's perspective deeply on the OCPs and to provide soliciting clarification and elaboration (Abdul-Aziz and Wong, 2010). On the other words, an interview is functioned to apprehend the issues from respondents' points of view. The interview was performed after completing data analysis of questionnaires.

Descriptive statistical analysis was used to exhibit the main figures of the data collection in quantitative forms. Ranking analysis was employed by measuring the Relative Importance Index (RII) of each variable. A number of studies in construction management area (e.g. Bageis and Fortune, 2009; Enshassi, Arain and Al-Raee, 2010; Akadiri, 2011) used this method to determine the significance of variables. This method computes the importance level of each variable based on seven-points Likert scale from 1 = "Strongly Unimportant" to 7 = "Strongly Important". The Rll scores were then extrapolated to define criticality of variables, namely "Strongly Unimportant" ( $\leq 0.14)$, "Very Unimportant" (0.15-0.29), "Unimportant" (0.300.44), "Moderately Important" (0.45-0.59), "Important" (0.60-0.74), "Very Important" (0.75-0.89) and "Strongly Important" $(\geq 0.90)$. The Rll scores were measured using Equation 2.

$$
R \|=, \frac{W}{A . N}
$$

Where Rll is the rank index, $w$ is the weighting obtaining from total score given by respondent on each variable, $A$ is the highest rate ( 7 in this research) and $N$ is the number of respondents.

Kendall's coefficient of concordance (W) was applied to determine the degree of agreement among the respondents in questionnaire survey towards their rankings. The coefficient provides the consensus on a scale of 0 , it means that there is no agreement among the respondents or experts, to 1 , it indicates a perfect consensus or concordance.

The Spearman rank-order correlation coefficient $\left(r_{s}\right)$ measures the agreement of two parties on their rankings of the attributes (Lam et al., 2005). In this research, $r_{s}$ measured the agreement among the paired groups of respondents based on their position and years' experience such as between commissioners and directors, directors and heads of department (HoD), HoD and managers, and respondents with 10 to 20 years' experience and 21 to 30 years' experience. These measures aim to observe whether there is any significant inter-group agreement on the ranking of the entry mode choice or not. 


\section{DATA ANALYSIS}

\section{Demography of Respondents and Participating Firms}

Most of the respondents have a respectable position in their companies and great experiences in their industry as presented in Table 2. Returned surveys from 103 respondents was $65 \%$ response rate, which derived from companies' top management level, $32.04 \%$ from directors and $6.08 \%$ from commissioners. Almost half of the respondents (48.54\%) approximately have been working for more than 10 years but less than 20 years in their current firms. Those facts indicate that the respondents are reliable in providing credible data. Thus, their responses gained through the survey are trusted, important and reliable (Akadiri, 2011).

Table 2. Profile Respondent and Participating Company

\begin{tabular}{lcc}
\hline Profile & Frequency & Percentage (\%) \\
\hline Designation of respondent in company & 7 & \\
Board of commissioners' & 33 & 6.80 \\
Board of directors & 27 & 32.04 \\
Heads of department/division & 36 & 26.21 \\
Managers & & 34.95 \\
Respondent's experience & - & \\
< 10 years & 50 & 0.00 \\
10-20 years & 25 & 48.54 \\
$21-30$ years & 28 & 24.27 \\
> 30 & & 27.19 \\
Company's memberships & 41 & \\
AKI & 45 & 39.81 \\
Gapensi & 17 & 43.69 \\
AKI and Gapensi & & 16.50 \\
Category of company & 6 & \\
State-owned & 97 & 5.83 \\
National private & & 94.17 \\
Year of company establishment & - & \\
< 10 years & 11 & 0.00 \\
10-20 years & 45 & 10.68 \\
$21-30$ years & 38 & 43.69 \\
31-40 years & 9.89 \\
> 40 years & & \\
\hline
\end{tabular}

(continued on next page) 
Table 2. (continued)

\begin{tabular}{lcc}
\hline Profile & Frequency & Percentage (\%) \\
\hline Number of permanent staff & & \\
$<250$ staff & 27 & 26.21 \\
$251-500$ staff & 44 & 42.72 \\
$501-1,000$ staff & 28 & 27.18 \\
$>1,000$ staff & 4 & 3.88 \\
Type of company & & \\
General contractor & 81 & 78.64 \\
Specialist contractor & 22 & 21.36 \\
Have experience in OCP & & \\
Yes & 6 & 5.83 \\
No & 97 & 94.17 \\
\hline
\end{tabular}

Note: 'In a limited liability company in Indonesia, Board of Commissioners have duty to supervise management policies. They also give advice to the board of directors.

Table 2 shows that $94.17 \%$ of participating firms were private sectors while the rest was identified as state-owned enterprises (Badan Usaha Milik Negara [BUMN]). This figure implies that the responses are more likely to be the representative of private enterprises. Regarding the year of enterprise's establishment, participating firms were dominated by those which have been operated between 21 and 30 years (nearly $44 \%$ ) and 31 to 40 years $(36.89 \%)$. This evidence vividly shows that the collected data has properly represented, almost $90 \%$ by extensively experienced firms in Indonesia.

Miserably, Table 2 also describes that the involvement of Indonesian contractors in OCMs has been still scanty; not up to $5 \%$ of samples have operated abroad. This fact reflects that Indonesian contractors are still enjoying domestic market demand, while overseas markets have been not their focus nowadays.

\section{Descriptive Analysis}

Table 3 shows the responses of the question on the entry strategies preferably adopted by the respondents. In general, the average scores of the preferred entry modes ranged from 2.75 (licensing) to 6.61 (JVP), while the standard deviation (SD) values were relatively small, ranging from 0.049 to 0.104 . Thus, using the average score as a representative value for the data is acceptable. The standard error (SE) values are minor compared with the actual means, indicating that the sample was sufficiently representing the population. 
Table 3. Descriptive Analysis of the Observed Variables

\begin{tabular}{lccc}
\hline Observed Items & Mean & SD & SE \\
\hline Strategic alliance & 4.09 & 0.064 & 0.651 \\
LA & 4.26 & 0.085 & 0.863 \\
Licensing & 2.75 & 0.085 & 0.860 \\
JVP & 6.61 & 0.049 & 0.497 \\
JVC & 5.00 & 0.072 & 0.728 \\
BO & 6.15 & 0.051 & 0.521 \\
RO & 5.60 & 0.104 & 1.053 \\
SVP & 4.34 & 0.085 & 0.858 \\
SVC & 2.89 & 0.075 & 0.766 \\
BOT & 3.76 & 0.070 & 0.707 \\
\hline
\end{tabular}

\section{RII of Entry Mode Choice}

Table 4 shows the descending rating of preferred choice of market entry strategies. In general, the RII score of the entry modes ranged from 0.39 to 0.94 , which were distributed in five criticality categories. The respondents indicated that establishing JVP was "Strongly Important" followed by setting BO and RO with "Very Important" for each other. The table clearly indicated two strategies as unimportant modes to enter foreign markets, which were SVC and licensing.

The table also presents entry modes rating given by respondents based on their managerial position. Overall, there were not many differences among groups in choosing preferable strategies to enter foreign markets. They relatively considered JVP, BO and RO as the up most strategic choice to penetrate the markets. At glance, the table shows an agreement of the entry mode choice between the group of commissioners and directors. Three groups of respondents consisting of commissioners, directors and HoD situated licensing as the bottom most entry strategy. Unlike the three groups, managers listed SVC in the bottom line.

In order to simplify the groups of respondents based on their establishment, the respondents having experience 10 to 20 years, 21 to 30 years and above 30 years were further called as Group 1, Group 2 and Group 3 respectively. In terms of the ranking agreement, the groups reached consensus on two modes of entry, i.e., JVP and BO. In the lowest rank, licensing was considered by Group 1 and Group 2, while Group 3 placed SVC. Furthermore, Rll scores given by each group indicate that group 1 subsumed two most important strategies to enter the markets (JVP and $\mathrm{BO}$ ). At the same category, group 2 put JVP, BO and JVC, while Group 3 listed $B O, R O$ and JVC on it. Surprisingly, the latter group categorised JVP as a strongly important strategy to enter OCMs. 
Wahyudi P Utama et al.

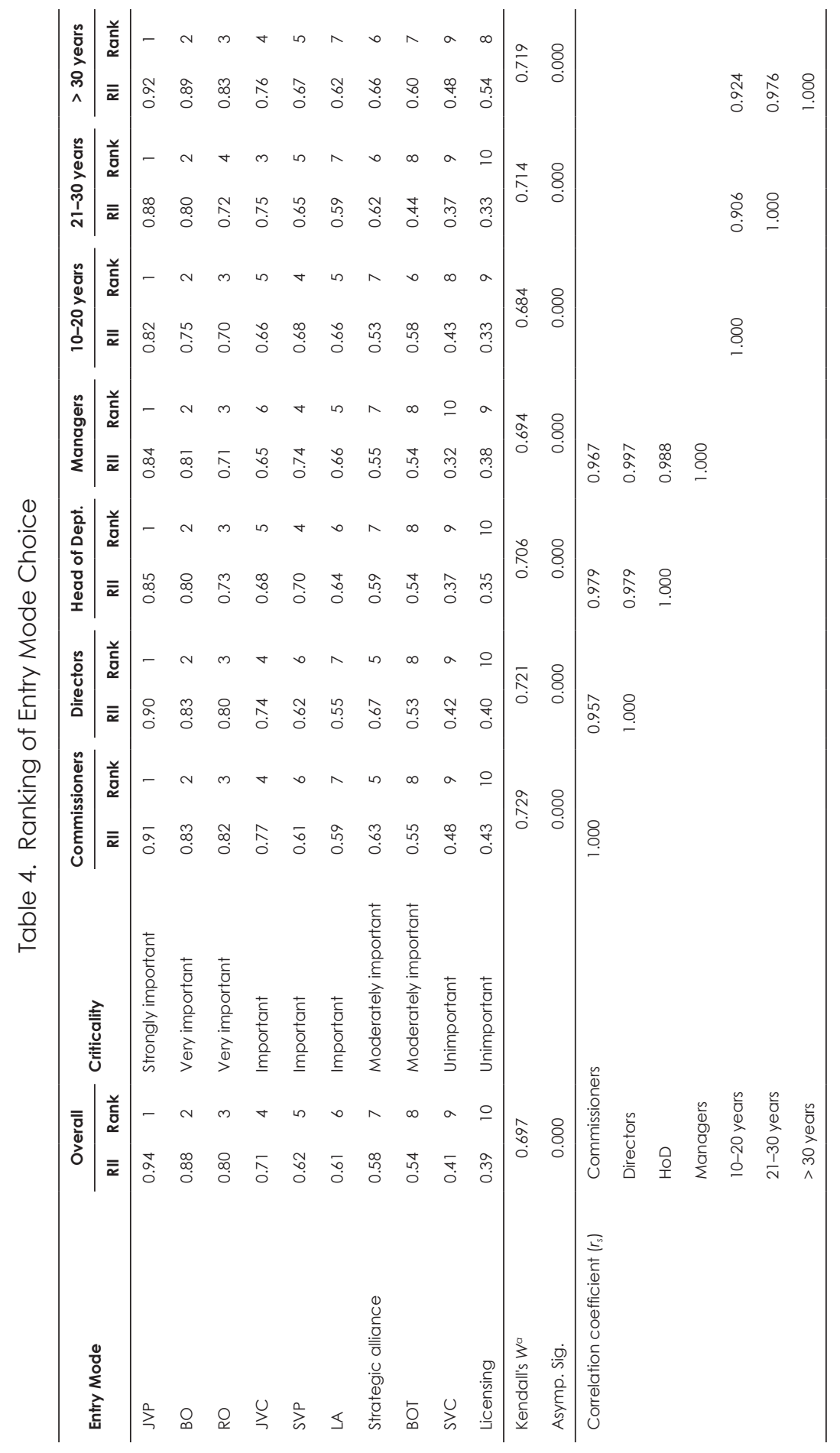


To confirm whether there were any significant intra-group differences among the respondents and each group of respondents, $W$ was measured. Overall, the concordance index for the ranking of entry mode choice was 0.697 at significant level of $99 \%$. These facts mean that there was a relatively strong consensus among respondents in each group's ranking. In the Table 4, the managerial groups recorded the $W$ values at $0.729,0.721,0.706$ and 0.694 respectively. These figures concluded that among respondents in each group of the managerial post had agreement on those rankings. Based on the respondents' experience, $W$ values were showed as follows: Group $1=0.684$, Group $2=0.714$ and Group $3=0.719$. These figures imply that there was an agreement among respondents in each group on the ranking of entry mode choice at a 0.001 significance level.

Similar indication was also found in the results of Spearman rank correlation of inter-groups toward the entry mode choice. The values of $r_{s}$ between paired groups of commissioners-directors, commissioners-HoD and commissioners-managers were 0.957, 0.979 and 0.967, respectively. Regarding companies' experience, Table 4 presents a significant agreement on the ranking of entry mode choice where the highest $r_{s}$ score of the entry mode choice was 0.976 belonging to the pair of respondents between Group 2 and Group 3.

All the results described above presents the opinions of respondents, which were merely obtained from analysis on responses of questionnaires. The weakness of this result is that it cannot be interpreted in-depth because there is limitation in using Likert scale in order to get further elaboration of the finding. Thus, interviews were carried out to clarify and support the above results.

\section{Validation}

Instead of quantitative approach, a qualitative method of validation was adopted to assess the findings validity. The qualitative approaches use opinion-based data in the form of word expressions and ideas (Roschke, 1994; Ameyaw, 2014). This method was applied as the nature of findings which lead to abstract constructs is inappropriate to be examined quantitatively (Ameyaw, 2014), while the number of suitable samples are scanty.

For this purpose, external validity which views generalisability of findings (Leedy and Ormrod, 2001) were carried out. Five practitioners who also the interviewees of this research were involved to answer a set of questions by choosing an appropriate rate based on four-point Likert scale ( 1 = Poor, 2 = Fair, $3=$ Good, $4=$ Very Good). The evaluation presents that the ranking of entry mode choice has very good external validity with a mean score of 3.8. The result indicates that the preferred entry mode choice could be generalised for Indonesian large contractors. 


\section{DISCUSSIONS}

\section{Preferred Choice of Entry Mode}

Analysis of the Rll scores as summarised in Table 4 shows that the respondents preferred to three types of entry modes including JVP, BO and RO. JVP indicates the importance of cooperation model, hierarchical level at project, contractual type and mobile mode as classified by Chen and Messner (2009). As argued by an academician as follows:

Indonesian firms' participation in OCPs through JVP will make them easier to compete rather than being a single fighter. Otherwise, a company must be supported by enough resources if adopting the competitive modes like SVP. Before joining JVP, one thing they should have is an experience in collaborating or in owning a network with foreign entities.

Almost similar to the opinion of the academician, a government officer underlined that low competitiveness and less experience in developing network with foreign institutions, even in domestic market, are the major factors hampering the expansion. He highlights, for those who ever interacted with respective foreign companies such as from Japan and Korea, this experience relatively aids them to enter foreign markets and make collaboration with foreign entities. Another interviewee claims that, his company entered Timor-Leste market via JVP with a local partner. He opined that, "JVP is a simple and flexible way to enter foreign markets, particularly for companies from a country, like Indonesia, whose government policies have a lack support in international competition". A practitioner said that:

We enter Libya market through JVP by collaborating with a Libyan investment company, the sharing was $70 \%$ our firm and $30 \%$ partner. This is our first project in Libya where the company performs a management service project. Reflecting on political situation in this country, entering foreign market via JVP is safer or less risky than having an investment type or a sole venture.

Similar to consulting firms from neighboring country, Malaysia, JVP was voted as the most preferred mode to enter foreign markets (Abdul-Aziz and Law, 2012). The Malaysian consultant firms highlighted personal business networks with clients and lead consultant firms to enter overseas markets. The difference is that Malaysian firms entered the host markets dominantly through "piggybacking" on Malaysian clients and consultants. Conversely, Indonesian companies preferred to collaborate with the host companies. JVP with local firms has been witnessed as a strategic step to enter host markets over the years. The multinational companies from developed industries like the US, Germany and Japan have even been adopted this strategy (Chen and Messner, 2011).

Following the JVC as a very effective and the most preferred entry strategy, establishing $\mathrm{BO}$ and $\mathrm{RO}$ in host country were also viewed as favored strategic plan of Indonesian contractors. According to an interviewee, the main reasons why the Indonesian contractors preferred to BO or RO after JVP are usually encouraged 
by the attractiveness of the market and the readiness of companies to compete against competitors. It indicates that the contractors have paid more attention and want to concentrate on the markets. These phenomena can be seen clearly in which the number of $\mathrm{BO}$ s and ROs belong to Indonesian institutions in Timor-Leste are more than in other countries. Dissenting opinion was given by another interviewee:

Choosing $\mathrm{BO}$ or RO as an entry strategy may create a management's burden for parent company. In fact, it is not applicable with most of Indonesian contractors which have limited resources. Thus, pursuing one-off projects through JVP or as a nominated subcontractor/supplier is precisely more practicable than establishing $\mathrm{BO}$ or $\mathrm{RO}$. It is because only strong companies, such as BUMNs and a few of private contractors can afford this mode. The setting of $\mathrm{BO}$ or RO in host markets obliges the company to obey the host country's regulations and policies which sometimes diminish their competitiveness.

In contrast to the later opinion, the academician argues that although by establishing $\mathrm{BO}$ or RO lessens the flexibility and mobility of company in foreign market penetration, this mode constitutes an optimistic strategy of expansion to well-identified markets. Instead of hunting projects in numerous countries, putting highly concentration on one to two well-known overseas markets is more effective and efficient.

Entering foreign markets through LA is a special case. It is a practical compulsory in the Gulf countries. According to Chen and Messner (2009), the aim of this policy is to enable the government to control the qualification of foreign firms, whereas Schirmer (1996) impugns the effectiveness of this mode in construction industry. An interviewee having experience in Oman and United Arab Emirates (UAE) said that:

We entered Dubai for a construction project through a sponsor (agent). The agent guaranteed and assisted us in preparing everything related to work permits, licenses and taxes. The sponsor fee is based on percentage of the executed works. The existence of a sponsor, on one hand, helps government to control the foreign firms, on the other hand, it convinces the project's owner on the firms' expertise. Without employing a sponsor, we cannot enter this country market.

Given the arguments above, in terms of the characteristic, JVP and BO or $\mathrm{RO}$ are types of strategy which are conflicting. As indicated about JVP, BO or RO urges competitive approach instead of cooperative model, hierarchical level at corporate as alternative of project level, investment pattern as replacement for contractual form and permanent model as substitution of mobile model. It can be concluded that the selection of such modes by respondents tends to disobey the characteristic. Perhaps, there are other considerations affecting the choice of mode by respondents, which are beyond of this research scope. 


\section{Transformation of Strategy to Enter Overseas Markets}

The results of questionnaires on the entry mode were fully confirmed by interview findings. As argued by Chen (2008), the application of single entry mode is unpractical. The companies commonly alloy two or three types of entry strategies depending on situation and condition of the host country market environment. In the Indonesian contractors' cases, five modes (JVP, SVP, LA, BO or RO) were employed at the first time entering the host country. Interestingly, each initial entry was followed by establishing $\mathrm{BO}$ or RO if the company wants to develop and maintain business further in the host country markets. This fact indicates that the selection of entry mode is not a rigid decision. Figure 1 may illustrate the transformation of the entry modes, which can be used by Indonesian contractors in the expansions.

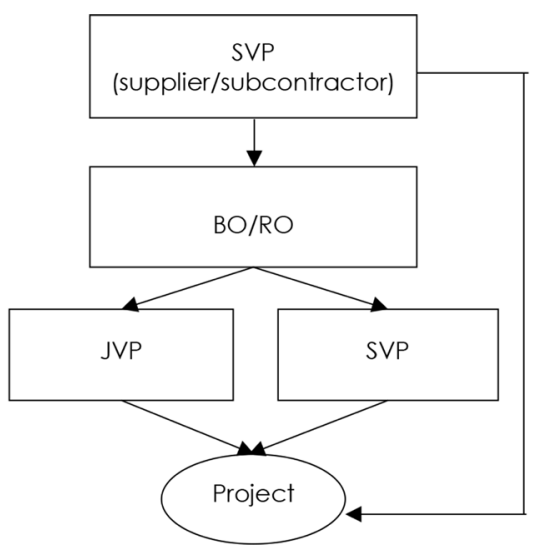

(a)

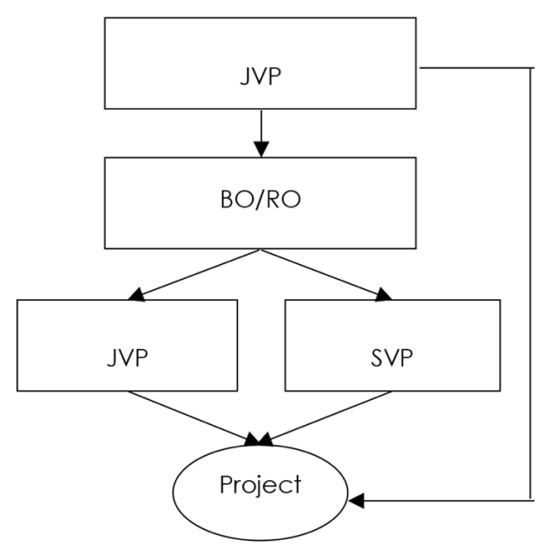

(c)

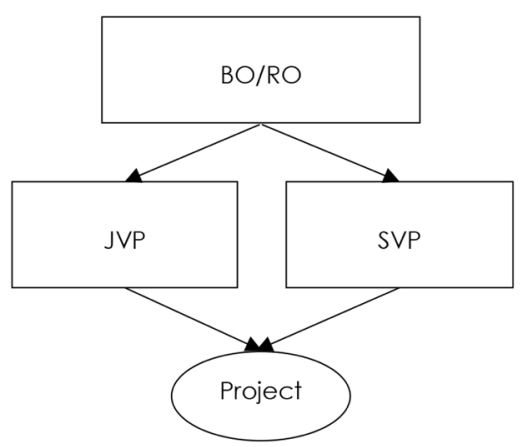

(b)

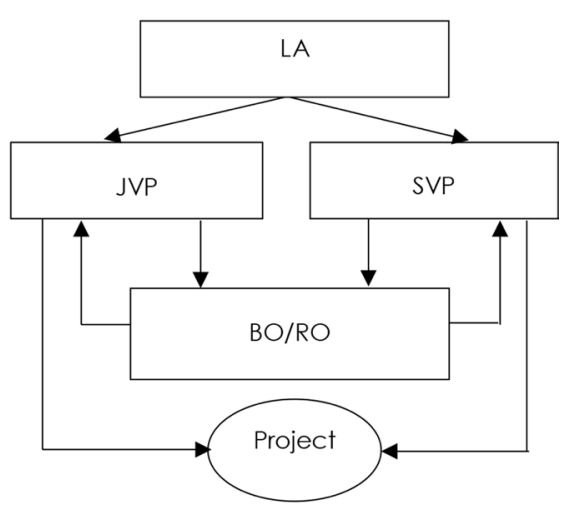

(d)

Figure 1. Transformation Models of Entry Strategy 
First, Figure 1 (a) shows that the company entered a market through SVP. The company competes or negotiates a work package belonging to a main contractor or a consortium either as a material/manpower supplier or a subcontractor. Based on the first experience in the market, company then sets a $\mathrm{BO}$ or RO if it considers building the business. On behalf of head office, $\mathrm{BO}$ or RO researches the market and develops networking for business establishment. After that, the company commonly sets a JVP with the local firms or directly competes as a single entity depending on the targeted project in the host country.

Second, the company directly sets a BO or RO in a targeted foreign market as presented in Figure 1 (b). This approach is usually employed when the company's management has design a strategic expansion planning on a foreign market, which is vividly identified. This approach has been adopted by several contractors to enter Timor-Leste. After setting a BO or RO, the company can apply JVP with local enterprises or SVP on a targeted project.

Third, the company enters the host market through a JVP, commonly with local firms as described in Figure 1(c). A BUMN entered Indian market via JVP with two local firms for a railway project, but then the company exited the country after a contractual dispute with client. Unlike the BUMN case, a private enterprise entered Timor-Leste through JVP with local firm for a power plan and subsequently it established a RO. As representation of the parent office, RO personnel assist the company to build up networking, promote the company and gather the information related to the company's business. Similar to the previous transformation, JVP or SVP can be employed for getting projects directly.

Fourth, the company enters a market via a LA as illustrated in Figure 1(d). A LA will carry out works related to his duties based on host country regulations such as assisting the contractor to get a recommendation for a project. Referring to the literature, only in the Middle East market such as UAE and Saudi Arabia where each foreign company intending to participate in the projects must engage a commercial agent service. Despite of the agent, the responsibility to get the projects still belongs to the company. An agent is only a sponsor to enable operation in the host market. So, the project pursuance is obtained from SVP and JVP. After obtaining few experiences in the market, the company then launches BO or RO if it intends to focus on and sustain business in the market.

\section{CONCLUSION}

Globalisation and free market era have offered a great opportunity for enterprises from developing construction industries to expand their market business internationally. This study aims to empirically investigate the entry strategy adopted by Indonesian contractors and to observe the transformation of strategy to enter overseas construction markets (OCMs). The statistical descriptive analysis of the questionnaires and relative important index revealed that Indonesian contractors preferred to adopt JVP, BO and RO.

From several entry processes of Indonesian enterprises to foreign markets, this study has illustrated four models of entry mode transformations that can be adopted by Indonesian contractors. It is interesting to note the attendance of four entry strategies (JVP, SVP, BO and RO) in each model of the transformation. 
Referring to characteristic of each entry mode, the result indicated that Indonesian contractors prefer to combine flexibility, contractual high risk and high control level in overseas operation.

Although, this study has not covered the entry mode issues comprehensively and has small implication to the broader communities, the findings may provide a profound insight based on developing industries' experiences. The enterprises from similar developing industries may learn and duplicate the knowledge. Furthermore, it significantly contributes to the body of knowledge in which the research development of developing industries has still been scarcity.

Lastly, one of several limitations of this study has not pertained the perspective of classical organisational theories like Dunning's eclectic paradigm and Porter's diamond concept, which get in touch with entry mode choice. Therefore, further research on the ground of the organisational theories influencing entry mode selection is strongly recommended.

\section{ACKNOWLEDGEMENTS}

This research is funded by the Ministry of Research, Technology and Higher Education, Republic of Indonesia. The authors thank to Universitas Bung Hatta, Indonesia and The Hong Kong Polytechnic University for their support.

\section{REFERENCES}

Abdul-Aziz, A.R. and Law, Y.H. (2012). Civil engineering consultants from developing countries: An exploration of Malaysian firms. International Journal of Construction Management, 12(2): 1-21. https://doi.org/10.1080/15623599.20 12.10773187.

Abdul-Aziz, A.R. and Wong, S.S. (2010). Exploring the internationalization of Malaysian contractors: The international entrepreneurship dimension. Construction Management and Economics, 28(1): 51-61. https://doi. org/10.1080/01446190903460680.

Akadiri, O.P. (2011). Development of a multi-criteria approach for the selection of sustainable materials for building projects. PhD diss. University of Wolverhampton.

Ameyaw, E.E. (2014). Risk allocation model for public private partnerships water supply projects in Ghana. PhD diss. The Hong Kong Polytechnic University.

Bageis, A.S. and Fortune, C. (2009). Factors affecting the bid/no bid decision in the Saudi Arabian construction contractors. Construction Management and Economics, 27(1): 53-71. https://doi.org/10.1080/01446190802596220.

Chen, C. (2008). Entry mode selection for international construction markets: The influence of host country related factors. Construction Management and Economics, 26(3): 303-314. https://doi.org/10.1080/01446190701882382.

Chen, C. and Messner, J.I. (2011). Characterizing entry modes for international construction markets: Paving the way to a selection model. Engineering, Construction and Architectural Management, 18(6): 547-567. https://doi. org/10.1108/09699981111180872. 
(2009). Entry mode taxonomy for international construction markets. Journal of Management in Engineering, 25(1): 3-11. https://doi.org/10.1061/ (ASCE)0742-597X(2009)25:1(3).

Chen, C. and Orr, R. (2009). Chinese contractors in Africa: Home government support, coordination mechanisms and market entry strategies. Journal of Construction Engineering and Management, 135(11): 1201-1210. https://doi. org/10.1061/(ASCE)CO.1943-7862.0000082.

Chen, L.Y. and Mujtaba, B. (2007). The choice of entry mode strategies and decision for international market expansion. The Journal of American Academy of Business, 10(2): 322.

Czaja, R. and Blair, J. (1996). Designing Surveys: A Guide to Decisions and Procedures. Thousand Oaks, CA: Pine Forge Press.

Enshassi, A., Arain, F. and Al-Raee, S. (2010). Causes of variation orders in construction projects in the Gaza Strip. Journal of Civil Engineering and Management, 16(4): 540-551. https://doi.org/10.3846/jcem.2010.60.

Lam, K.C., Tang, C.M. and Lee, W.C. (2005). Application of the entropy technique and genetic algorithms to construction site layout planning of medium-size projects. Construction Management and Economics, 23(2): 127-145. https:// doi.org/10.1080/0144619042000202834.

Leedy, P.D. and Ormrod, J.E. (2001). Practical Research Planning and Design. 7th Ed. Upper Saddle River, NJ: Prentice-Hall.

Li, H., Jin, Z., Li, V., Liu, G. and Skitmore, R.M. (2013). An entry mode decision-making model for the international expansion of construction enterprises. Engineering, Construction and Architectural Management, 20(2): 160-180. https://doi. org/10.1108/09699981311303026.

Ling, F.Y.Y., Ibbs, C.W. and Cuervo, J.C. (2005). Entry and business strategies used by international architectural, engineering and construction firms in China. Construction Management and Economics, 23(5): 509-520. https://doi. org/10.1080/01446190500040141.

Maqsoom, A., Charoenngam, C., Masood, R. and Awais, M. (2014). Foreign market entry considerations of emerging economy firms: An example of Pakistani contractors. Procedia Engineering, 77: 222-228. https://doi.org/10.1016/j. proeng.2014.07.020.

Pan, Y. and Tse, D.K. (2000). The hierarchical model of market entry modes. Journal of International Business Studies, 31(4): 535-554. https://doi.org/10.1057/ palgrave.jibs.8490921.

Pheng, S.L. and Hongbin, J. (2003). Internationalization of Chinese construction enterprises. Journal of Construction Engineering and Management, 129(6): 589-598. https://doi.org/10.1061/(ASCE)0733-9364(2003)129:6(589).

Preece, C.N., Isa, C.M.M., Saman, H.M. and Ibrahim, C.K.C. (2016). Development of entry location, entry timing and entry mode decision model for construction firms in international markets. Construction Management and Economics, 34(4-5): 236-257. https://doi.org/10.1080/01446193.2015.1084429.

Root, F.R. (1994). Entry Strategies for International Markets. Lexington, USA: Lexington Books.

Roschke, P.N. (1994). Validation of knowledge-based system with multiple bridge rail experts. Journal of Transportation Engineering, 120(5): 787-806. https://doi. org/10.1061/(ASCE)0733-947X(1994) 120:5(787). 
Schirmer, H.J. (1996). Global expansion: A growing dilemma. Journal of Management Engineering, 12(5): 28-31. https://doi.org/10.1061/(ASCE)0742$597 \times(1996) 12: 5(28)$.

Tjandra, I.K. (2004). Organisational learning in construction: The case of construction firms in Jakarta, Indonesia. PhD diss. National University of Singapore.

Utama, W.P., Chan, A.P.C., Zahoor, H. and Gao, R. (2016). Review of research trend in international construction projects: A bibliometric analysis. Construction Economics and Building, 16(2): 71-82. https://doi.org/10.5130/AJCEB. v16i2.4866.

Willard, D. (2012). Improving quality management system implementation in Indonesian construction companies. PhD diss. Queensland University of Technology. 